\title{
PENGUATAN STRATEGI UNTUK PENGEMBANGAN MINAPOLITAN KABUPATEN CILACAP
}

\section{Reinforcement Strategy for the Development of Minapolitan in the Cilacap Regency}

\author{
*Agus Dwi Nugroho', Andi Rifani², Winaryo ${ }^{3}$, Edy Masduqi ${ }^{4}$, Dyah Wahyuning Tyas ${ }^{5}$, \\ Rochma Widayanti², Reni Aqwil Masithah², Ridwan Dicky Romadon², \\ Teguh Sulissetiyo ${ }^{2}$, Reiningsih ${ }^{2}$, dan Alwi Handono Topo $^{2}$ \\ ${ }^{1}$ Fakultas Pertanian, Universitas Gadjah Mada \\ JL. Flora, Bulaksumur, Kabupaten Sleman, Daerah Istimewa Yogyakarta 55281, Indonesia \\ ${ }^{2}$ Greenterra Mapindo \\ ${ }^{3}$ Pusat Studi Bencana Alam Universitas Gadjah Mada \\ ${ }^{4}$ Institut Teknologi Yogyakarta \\ ${ }^{5}$ Sekolah Tinggi Pariwisata Ambarrukmo
}

Diterima tanggal: 26 Agustus 2019 Diterima setelah perbaikan: 10 Desember 2020

Disetujui terbit: 23 Desember 2020

\begin{abstract}
ABSTRAK
Pengembangan kawasan minapolitan di Kabupaten Cilacap belum menunjukkan kinerja optimal. Hal tersebut merupakan indikasi bahwa kebijakan pengembangan minapolitan masih belum efektif. Tujuan penelitian ini adalah mengetahui eksisting kawasan minapolitan Kabupaten Cilacap dan penguatan strategi untuk pengembangan kawasan tersebut. Penelitian dilaksanakan pada Mei sampai dengan Agustus 2019 di kawasan minapolitan Kabupaten Cilacap. Jenis data yang digunakan adalah data primer yang diperoleh dari wawancara dan FGD serta data sekunder yang diperoleh dari studi dokumen. Metode yang digunakan dalam analisis data antara lain deskriptif dan SWOT. Kondisi alam yang bagus serta sumber daya manusia yang cukup baik merupakan kekuatan utama pengembangan minapolitan. Namun, minapolitan Kabupaten Cilacap masih menghadapi masalah infrastruktur yang rusak serta akses permodalan, pemasaran, dan pengolahan hasil yang belum sepenuhnya mendukung pengembangan minapolitan. Untuk meningkatkan kinerja kawasan minapolitan, Kabupaten Cilacap perlu melakukan strategi S-O melalui penguatan kelembagaan perikanan dan regenerasi SDM, memperluas jaringan kemitraan, baik hulu dan hilir serta sektor lain (pariwisata); promosi komoditas perikanan; dan pengadaan/pembuatan infrastruktur budi daya dan pemasaran produk.
\end{abstract}

Kata Kunci: minapolitan; deskriptif; SWOT, Kabupaten Cilacap

\begin{abstract}
The development of minapolitan area in Cilacap Regency has not shown an optimal performance. This is an indication that development strategy of minapolitan area has not been effective. The study aimed to identify the existing minapolitan area in Cilacap Regency as well as to reinforce the development strategy for the area. The research was conducted from May to August 2019 in the minapolitan area of Cilacap Regency. The study used primary data that were collected from interview and FGD as well as secondary data that were collected from document study. The analysis models used descriptive and SWOT analysis. The great natural and human resources are the main forces in minapolitan development. However, this minapolitan area is facing infrastructure damage and poor access of capital, marketing and product processing. Therefore, it is necessary to undertake an S-O strategy through reinforcement of fisheries institution and human resources, expansion of partnership networks, both upstream to downstream and other sectors (tourism); promotion of fisheries commodities; and procurement / manufacturing of aquaculture infrastructure and product marketing.
\end{abstract}

Keywords: minapolitan; descriptive; SWOT; Regency Cilacap 


\section{PENDAHULUAN}

Kabupaten Cilacap memiliki potensi perikanan budi daya dan perikanan tangkap sangat besar. Kawasan perikanan tangkap Cilacap ada di wilayah SegaraAnakan (Satria \& Kurnia, 2017). Keberadaan sumber daya perairan Segara Anakan memberikan kontribusi ekonomi yang cukup besar baik bagi masyarakat maupun pemerintah. Komoditas unggulan wilayah tersebut antara lain ikan, kepiting dan udang (Triyanti, Wijaya, Koeshendrajana \& Priyatna, 2010). Potensi perikanan air tawar di Cilacap juga sangatlah besar untuk menjadi sumber pendapatan daerah (Nuryanto, Bhagawati, Abulias \& Indarmawan, 2015). Namun begitu, pemanfaatan potensi perikanan di Kabupaten Cilacap masih belum berkembang secara optimal. Kondisi kualitas sumber daya manusia dan sarana penangkapan yang masih belum memadai menjadi penyebab kurang optimalnya pengembangan perikanan (Pancawati, 2015). Salah satu solusi untuk mengatasi masalah ini dan mempercepat perkembangan potensi perikanan adalah dengan membentuk kawasan minapolitan budi daya dan tangkap di Kabupaten Cilacap. Kawasan minapolitan tersebut merupakan salah satu unggulan di Provinsi Jawa Tengah (Febriyanti, 2013).

Pengembangan kawasan minapolitan di tingkat daerah harus mengacu pada kebijakan pusat agar terintegrasi dengan wilayah sekitar. Namun, pemerintah daerah perlu juga menyusun peraturan agar minapolitan mampu mengkaitkannya dengan potensi lain di daerah tersebut. Peraturan Menteri Kelautan dan Perikanan No. 12 Tahun 2010 menyatakan kawasan minapolitan konsepsi pembangunan ekonomi kelautan dan perikanan berbasis kawasan berdasarkan prinsip terintegrasi, efisiensi, berkualitas dan percepatan. Konsep dasar pengembangan kawasan minapolitan adalah upaya menciptakan pembangunan inter-regional berimbang, khususnya dengan meningkatkan keterkaitan pembangunan kota-desa (Kementerian Kelautan dan Perikanan, 2013). Kebijakan minapolitan ini terbukti mampu meningkatkan produksi dan pendapatan pelaku usaha perikanan (Kurniawan, 2018).

Namun begitu, hasil kajian mengenai minapolitan di Indonesia menunjukkan bahwa kawasan ini memiliki peluang keberlanjutan yang rendah. Hal ini disebabkan karena kondisi alam kurang mendukung, rendahnya produktivitas usaha, minimnya ketersediaan dan keterlibatan SDM, kurangnya industri pengolahan limbah, dan kebijakan yang kurang mendukung (Widyaningrum, 2016; Wiratama, 2016). Kondisi tersebut juga terjadi pada minapolitan di Kabupaten Cilacap dimana pengembangannya belum optimal karena baru terbatas pada penyediaan sarana dan prasarana minapolitan, namun belum ada keterkaitan menyeluruh antara subsistem hulu, subsistem hilir, dan subsistem penunjang kawasan minapolitan (Suryawati \& Purnomo, 2011). Hal ini menunjukkan bahwa strategi pengembangan minapolitan yang dilakukan Pemerintah Kabupaten Cilacap belum efektif.

Dampak dari tidak efektifnya implementasi minapolitan adalah tidak terintegrasinya subsistem hulu dengan hilir di Kabupaten Cilacap. Hal tersebut menyebabkan usaha perikanan di Kabupaten Cilacap tidak efisien karena kenaikan biaya transaksi (Patria, Adrianto, Kusumastanto, Kamal \& Dahuri, 2014). Kondisi ini kemudian menimbulkan multiplier effectt berupa penurunan pendapatan riil masyarakat di sektor perikanan Kabupaten Cilacap (Ramadhan \& Hafsaridewi, 2012). Bahkan, beberapa komoditas perikanan di Kabupaten Cilacap, seperti udang, diprediksi pada masa mendatang akan mengalami penurunan manfaat ekologis dan ekonomi (Pangesti, 2015). Dengan begitu, diperlukan suatu kajian dengan tujuan mengetahui eksisting Kawasan Minapolitan Kabupaten Cilacap dan pengembangan strategi untuk penguatan kawasan tersebut.

\section{METODOLOGI}

\section{Lokasi dan Waktu Penelitian}

Pada prinsipnya, penelitian ini dimulai dengan mengidentifikasi konsep mengenai minapolitan. Hal ini dapat dilakukan dengan melihat dokumen mengenai perencanaan kawasan minapolitan di tingkat nasional, Provinsi Jawa Tengah, dan Kabupaten Cilacap. Selanjutnya, perlu dilihat implementasi kawasan minapolitan di Kabupaten Cilacap. Aktivitas ini dilakukan dengan meninjau kondisi eksisting kawasan minapolitan, pernyataan stakeholder, dan kebijakan pendukung dalam mengelola kawasan tersebut. Dari keduanya, maka akan diperoleh gap antara konsep minapolitan dengan impelementasinya dan kebijakan pendukung di Kabupaten Cilacap. Identifikasi gap tersebut dilakukan dengan analisis deksriptif mengenai teknis (sumber daya alam, infrastruktur, dan sarana produksi), sosial ekonomi masyarakat (kualitas sumber daya manusia, permodalan, pemasaran, dan pengolahan hasil), 


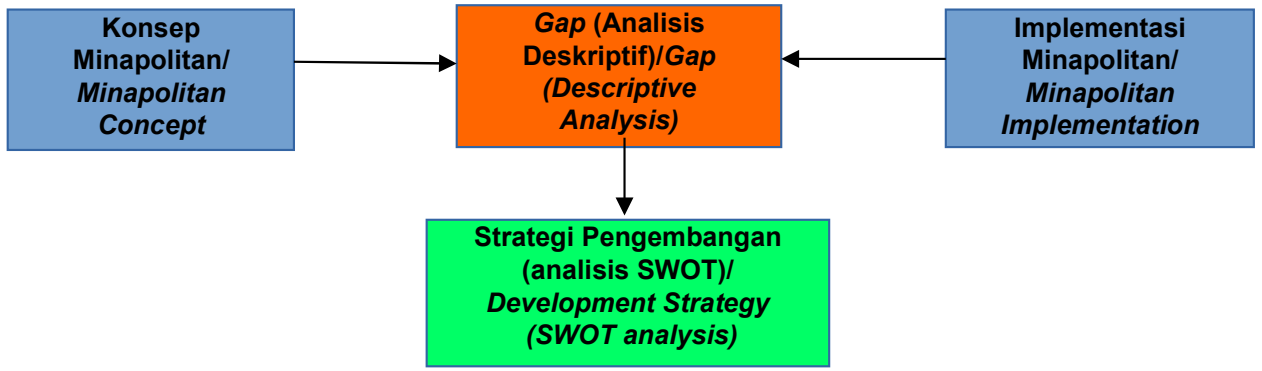

Gambar 1. Kerangka Pemikiran Penelitian.
Figure 1. Framework of the Research.

dan berbagai kebijakan pendukungnya. Setelah teridenftikasi gap, maka selanjutnya dilakukan analisis SWOT. Analisis dilakukan dengan melihat kekuatan, kelemahan, peluang, dan ancaman kawasan minapolitan sehingga akan teridentifikasi berbagai strategi dalam pengembangan kawasan tersebut.

\section{Jenis dan Metode Pengumpulan Data}

Jenis data yang digunakan dalam penelitian adalah data primer dan data sekunder. Data primer diperoleh dari wawancara responden dan Focus Group Discussion. Data primer yang diperoleh berupa, antara lain kondisi kawasan minapolitan serta faktor internal dan eksternal dalam pengembangan minapolitan, sedangkan data sekunder berupa dokumen yang diperoleh dari Organisasi Perangkat Daerah (OPD) di Kabupaten Cilacap. Jenis dokumen yang digunakan dalam penelitian ini antara lain Cilacap dalam Angka, RTRW, RPJMD dan kajian feasibility study mengenai minapolitan di Kabupaten Cilacap.

Sampel responden pada aktivitas wawancara adalah 2 orang staf Dinas Perikanan dan 30 orang pembudi daya ikan/nelayan. FGD dilakukan sebanyak 3 (tiga) kali dengan OPD terkait yaitu Badan Perencanaan Penelitian dan Pengembangan Daerah, Dinas Perikanan, Dinas Perdagangan Koperasi dan Usaha Kecil Menengah, Dinas Penanaman Modal dan Pelayanan Terpadu Satu Pintu, Dinas Pekerjaan Umum dan Penataan Ruang, dan Dewan Riset Daerah.

Penelitian ini dilaksanakan di Kabupaten Cilacap pada bulan Mei sampai dengan Agustus 2019. Lokasi penelitian adalah kecamatan yang telah ditetapkan sebagai kawasan minapolitan oleh Pemerintah Daerah Kabupaten Cilacap maupun kecamatan lain di sekitar kawasan minapolitan atau kecamatan yang direkomendasikan oleh Dinas Perikanan.

\section{Metode analisis}

\section{Analisis Deskriptif}

Analisis ini digunakan untuk mengetahui keadaan eksisting kawasan minapolitan Kabupaten Cilacap. Indikator yang digunakan dalam analisis ini diantaranya sumberdaya alam (natural capital), sumber daya manusia dan kelembagaan masyarakat (human capital dan social capital), dan prasarana (Kementerian Kelautan dan Perikanan, 2013). Keempat indikator tersebut merupakan syarat wajib bagi penerapan minapolitan. Dari indikator tersebut kemudian didetailkan menjadi keadaan sumber daya alam, infrastruktur, kelembagaan sarana produksi, kelembagaan nelayan, kelembagaan permodalan, kelembagaan pemasaran, dan kelembagaan/Industri pengolahan hasil UMKM. Setiap responden nantinya akan memberikan bobot 0-100 bagi setiap indikator. Rentang bobot yang besar ini untuk memberikan kemudahan bagi responden menilai setiap indikator. Bobot tersebut akan dirata-rata sehingga dapat diklasifikasikan menjadi kurang (skor rata-rata 0-33), sedang (skor rata-rata 34-67), dan bagus (68-100).

\section{Analisis SWOT}

Untuk menyusun strategi pengembangan kawasan minapolitan di Kabupaten Cilacap digunakan analisis SWOT (Strengths, Weaknesses, Opportunities, Threats). Analisis SWOT dilakukan dengan cara mengidentifikasi berbagai faktor secara sistematis untuk merumuskan kebijakan dan strategi (Gurel \& Tat, 2017). Faktor dilihat dari 2 sisi yakni internal dan eksternal. Faktor internal atau biasa disebut Internal Strategic Factors Analysis Summary (IFAS) terdiri dari kekuatan (strengths) dan kelemahan (weakness). Faktor eksternal atau External Strategic Factors Analysis Summary (EFAS) terdiri dari peluang (opportunities) dan ancaman (threats). Faktor internal dan eksternal 
diperoleh dari observasi di lapangan, studi dokumen, dan wawancara dengan pemangku kebijakan.

Analisis SWOT pada penelitian ini menggunakan nilai rating dan bobot. Rating diperoleh melalui wawancara langsung dengan pelaku perikanan di kawasan minapolitan. Nilai rating berupa skala dari 1-4 dimana 1 apabila responden sangat tidak setuju dengan pernyataan di kuesioner, 2 adalah tidak setuju, 3 merupakan setuju, dan 4 apabila responden sangat setuju. Sedangkan nilai bobot berasal dari pemangku kebijakan (stakeholder) dalam usaha perikanan (Dinas Perikanan). Responden akan menilai bobot tiap pernyataan pada tiap faktor serta memberikan nilai dari skala 0-100. Skala 0 menunjukkan faktor tersebut tidak penting sedangkan skala 100 menunjukkan faktor sangat penting bagi pengembangan minapolitan. Rating dan bobot yang sudah diperoleh selanjutnya digunakan untuk menghitung total skor dari masing-masing indikator pada masing-masing faktor yang telah ditentukan (Gurel \& Tat, 2017).

Hasil dari analisis SWOT akan menghasilkan posisi dari kawasan minapolitan Kabupaten Cilacap dalam suatu matriks. Dari posisi tersebut, maka akan disusun strategi pengembangan dan pemberdayaan masyarakat di sekitar wilayah kawasan minapolitan.

\section{HASIL DAN PEMBAHASAN}

\section{Kondisi Eksisting Kawasan Minapolitan}

Penetapan kawasan minapolitan di daerah Kabupaten Cilacap sesuai dengan Rencana Tata Ruang Wilayah Kabupaten Cilacap Tahun 2011 - 2031 pada Peraturan Daerah Kabupaten Cilacap Nomor 9 Tahun 2011 adalah Kecamatan Maos, Sampang, Dayeuhluhur, Wanareja, Majenang, dan Cilacap Selatan. Setiap kecamatan tersebut memiliki jenis usaha perikanan yang berbeda. Kecamatan Maos (Desa Maos Lor, Maos Kidul, Kalijaran, Panisihan, dan Glempang), Kecamatan Sampang (Desa Karangjati, Karangasem dan Karangtengah), Kecamatan Dayeuhluhur (Desa Dayeuhluhur, Bolang dan Hanum), Kecamatan Wanareja (Desa Wanareja, Limbangan, Tarisi dan Madura), dan Kecamatan Majenang (Desa Jenang, Cibeunying, Salebu, dan Pahonjean) berbasis perikanan budi daya serta Kecamatan Cilacap Selatan (Kelurahan Cilacap, Sidakaya dan Tegalkamulyan) berbasis perikanan tangkap.
Untuk menentukan kondisi kawasan minapolitan, maka dilakukan analisis deskriptif berdasarkan indikator sumber daya alam (SDA), infrastruktur, kelembagaan sarana produksi, kelembagaan nelayan, kelembagaan permodalan, kelembagaan pemasaran, dan kelembagaan/ Industri pengolahan hasil UMKM. Indikator tersebut merupakan salah satu acuan Kementerian Kelautan dan Perikanan untuk menilai kelayakan kawasan minapolitan. Indikator SDA menunjukkan kuantitas, kualitas, dan kontinuitas komoditas perikanan. Indikator infrastruktur terkait ketersediaan sarana prasarana input, budi daya maupun pengolahan dan pemasaran produk. Sedangkan kelembagaan terkait dengan ada/tidaknya lembaga penunjang setiap subsistem perikanan serta kualitas dari kelembagaan tersebut. Secara detail penilaian kawasan minapolita Kabupaten Cilacap tersaji pada Tabel 1.

Kawasan minapolitan di Kabupaten Cilacap memiliki potensi alam yang mendukung untuk usaha perikanan, baik budi daya maupun tangkap. Pada wilayah sepanjang pesisir pantai Kabupaten Cilacap terdapat berbagai potensi perikanan tangkap maupun perikanan budi daya. Nelayan memperoleh ikan dengan dua cara yakni mencari ikan ke laut lepas atau membuat tambak di sekitar pantai selatan Kabupaten Cilacap. Pada wilayah lain, beberapa kecamatan yang termasuk kawasan minapolitan memiliki keunggulan pada budi daya ikan air tawar. Usaha perikanan air tawar sangat didukung dengan sistem perairan cukup baik, berasal dari irigasi, sumur, dan air hujan.

Komoditas yang dibudi daya kan di kawasan minapolitan antara lain gurameh, nilem, mas, lele, sidat dan udang vaname. Komoditas perikanan yang dominan dibudi daya kan di kawasan minapolitan adalah ikan gurameh, ikan lele, dan udang vaname. Masalah utama dalam budi daya ikan adalah penyakit yang menyerang bagian tubuh ikan, misalnya bintik merah yang merupakan penyakit yang menyerang ikan gurameh, atau berak putih pada udang vaname. Sampai saat ini, upaya yang dilakukan pembudi daya ikan dan penyuluh perikanan terbukti mampu untuk mengurangi dampak serangan penyakit. Dengan begitu, wilayah minapolitan memiliki SDA yang sangat baik sehingga produksi ikan di Kabupaten Cilacap sangat tinggi.

Infrastruktur merupakan sistem yang dapat mendukung sistem sosial dan ekonomi yang secara 
Tabel 1. Kondisi Kawasan Minapolitan Kabupaten Cilacap Tahun 2019. Table 1. Condition of the Minapolitan Area in the Cilacap Regency 2019.

\begin{tabular}{|c|c|c|c|c|c|c|c|}
\hline \multirow[b]{2}{*}{$\begin{array}{l}\text { Kecamatan/ } \\
\text { Sub District }\end{array}$} & \multicolumn{7}{|c|}{ Kriteria / Criteria } \\
\hline & $\begin{array}{c}\text { SDA / } \\
\text { Natural } \\
\text { Resources }\end{array}$ & $\begin{array}{l}\text { Infrastrukturl } \\
\text { Infrastructures }\end{array}$ & $\begin{array}{l}\text { Sarana } \\
\text { Produksi/ } \\
\text { Production } \\
\text { Facilities }\end{array}$ & $\begin{array}{l}\text { Kelembagaan } \\
\text { SDM/Human } \\
\text { Resource } \\
\text { Institutions }\end{array}$ & $\begin{array}{c}\text { Permodalan/ } \\
\text { Capital }\end{array}$ & $\begin{array}{l}\text { Pemasaran/ } \\
\text { Marketing }\end{array}$ & $\begin{array}{c}\text { Pengolahan } \\
\text { Hasil dan UMKM/ } \\
\text { Processing and } \\
\text { SME }\end{array}$ \\
\hline Maos & $\begin{array}{l}\text { Bagus/ } \\
\text { Good }\end{array}$ & $\begin{array}{l}\text { Sedang/ } \\
\text { Medium }\end{array}$ & $\begin{array}{l}\text { Bagus/ } \\
\text { Good }\end{array}$ & $\begin{array}{l}\text { Sedang/ } \\
\text { Medium }\end{array}$ & $\begin{array}{c}\text { Kurang/ } \\
\text { Inadequate }\end{array}$ & $\begin{array}{l}\text { Bagus/ } \\
\text { Good }\end{array}$ & $\begin{array}{l}\text { Bagus } \\
\text { /Good }\end{array}$ \\
\hline Sampang & $\begin{array}{c}\text { Bagus/ } \\
\text { Good }\end{array}$ & $\begin{array}{l}\text { Sedang/ } \\
\text { Medium }\end{array}$ & $\begin{array}{l}\text { Bagus/ } \\
\text { Good }\end{array}$ & $\begin{array}{l}\text { Sedang/ } \\
\text { Medium }\end{array}$ & $\begin{array}{c}\text { Kurang/ } \\
\text { Inadequate }\end{array}$ & $\begin{array}{l}\text { Sedang/ } \\
\text { Medium }\end{array}$ & $\begin{array}{l}\text { Bagus } \\
\text { /Good }\end{array}$ \\
\hline Dayeuhluhur & $\begin{array}{l}\text { Bagus/ } \\
\text { Good }\end{array}$ & $\begin{array}{l}\text { Sedang/ } \\
\text { Medium }\end{array}$ & $\begin{array}{l}\text { Bagus/ } \\
\text { Good }\end{array}$ & $\begin{array}{l}\text { Sedang/ } \\
\text { Medium }\end{array}$ & $\begin{array}{l}\text { Kurang/ } \\
\text { Inadequate }\end{array}$ & $\begin{array}{l}\text { Bagus/ } \\
\text { Good }\end{array}$ & $\begin{array}{l}\text { Bagus } \\
\text { /Good }\end{array}$ \\
\hline Wanareja & $\begin{array}{l}\text { Bagus/ } \\
\text { Good }\end{array}$ & $\begin{array}{l}\text { Sedang/ } \\
\text { Medium }\end{array}$ & $\begin{array}{l}\text { Bagus/ } \\
\text { Good }\end{array}$ & $\begin{array}{l}\text { Sedang/ } \\
\text { Medium }\end{array}$ & $\begin{array}{c}\text { Kurang/ } \\
\text { Inadequate }\end{array}$ & $\begin{array}{l}\text { Bagus/ } \\
\text { Good }\end{array}$ & $\begin{array}{l}\text { Bagus } \\
\text { /Good }\end{array}$ \\
\hline Majenang & $\begin{array}{l}\text { Bagus/ } \\
\text { Good }\end{array}$ & $\begin{array}{c}\text { Kurang/ } \\
\text { Inadequate }\end{array}$ & $\begin{array}{c}\text { Kurang/ } \\
\text { Inadequate }\end{array}$ & $\begin{array}{l}\text { Sedang/ } \\
\text { Medium }\end{array}$ & $\begin{array}{l}\text { Kurang/ } \\
\text { Inadequate }\end{array}$ & $\begin{array}{c}\text { Kurang/ } \\
\text { Inadequate }\end{array}$ & $\begin{array}{c}\text { Kurang/ } \\
\text { Inadequate }\end{array}$ \\
\hline $\begin{array}{l}\text { Cilacap } \\
\text { Selatan }\end{array}$ & $\begin{array}{l}\text { Bagus/ } \\
\text { Good }\end{array}$ & $\begin{array}{l}\text { Sedang/ } \\
\text { Inadequate }\end{array}$ & $\begin{array}{l}\text { Bagus/ } \\
\text { Good }\end{array}$ & $\begin{array}{l}\text { Sedang/ } \\
\text { Medium }\end{array}$ & $\begin{array}{c}\text { Kurang/ } \\
\text { Inadequate }\end{array}$ & $\begin{array}{c}\text { Kurang/ } \\
\text { Inadequate }\end{array}$ & $\begin{array}{c}\text { Kurang/ } \\
\text { Inadequate }\end{array}$ \\
\hline
\end{tabular}

Sumber: Analisis data primer, 2019/Source: Primary data analysis, 2019

Keterangan/Remaks:

Bagus, mengidentifikasi sesuai kriteria pengembangan kawasan (rata-rata skor 68-100)/

Good, identify according to regional development criteria (average score 68-100)

Sedang, mengidentifikasi cukup sesuai kriteria pengembangan kawasan (rata-rata skor 34-67)/

Medium, identifyi sufficiently appropriate to regional development criteria (average score 34-67)

Kurang, mengidentifikasi kurang sesuai kriteria pengembangan kawasan (rata-rata skor 0-33)/

Inadequate, identify less appropriate to regional development criteria (averga score 0-33)

sekaligus menjadi penghubung sistem lingkungan. Aspek infrastruktur merupakan masalah utama yang dihadapi berdasarkan hasil survei yang telah dilakukan. Infrastruktur jalan di kawasan minapolitan masih banyak yang rusak. Sebagian besar responden menyatakan jalan yang rusak ini dapat menyulitkan proses pengangkutan input maupun output usaha perikanan. Kerusakan jalan ini dapat disebabkan karena banyaknya aktivitas kendaraan melebihi standar beban yang telah ditetapkan maupun cuaca yang tidak menentu. Pemerintah Kabupaten Cilacap perlu melakukan perbaikan jalan maupun pemberlakuan aturan secara tegas mengenai beban angkut maksimal. Kewenangan perbaikan infrastruktur jalan memang terbagi di tingkat pusat, provinsi, kabupaten, dan desa. Namun, kewenangan ini seharusnya tidak menjadi pembatas agar perbaikan jalan dilakukan secepatnya. Langkah utama yang perlu dilakukan adalah koordinasi antar instansi tersebut untuk memenuhi harapan masyarakat mengenai peningkatan kualitas infrastruktur jalan. Sedangkan aturan beban angkut maksimal perlu disosialisasikan kepada masyarakat dalam rangka mengurangi penyebab kerusakan jalan.

Begitu pula dengan infrastruktur pengairan yang belum maksimal sehingga menurunkan debit air untuk pengairan kolam budi daya. Berdasarkan hasil studi lapangan, jumlah irigasi yang masih rusak di kawasan minapolitan mencapai $38 \%$. Kerusakan irigasi paling banyak disebutkan oleh pelaku usaha perikanan di wilayah Kecamatan Majenang. Pemerintah Kabupaten Cilacap perlu menyusun desain infrastruktur yang terintegrasi antar wilayah serta implementasi pembangunan infrastruktur demi terwujudnya kawasan pengembangan minapolitan yang maju.

Berdasarkan hasil survei, aksesbilitas nelayan terhadap sarana produksi di Kabupaten Cilacap sangat baik. Nelayan dapat membeli sarana untuk kebutuhan produksi di seluruh wilayah karena tersedia di berbagai toko maupun sarana pemasaran lainnya, contohnya pakan dan BBM. Pembudi daya ikan memperoleh pelet dari distributor pakan maupun membeli online di internet. Secara ekonomi, nelayan juga mampu membeli sarana produksi karena nelayan memperoleh subsidi sarana produksi sehingga harganya lebih murah. Dengan keadaan tersebut, maka secara umum distribusi dan aksesbilitas sarana produksi di wilayah minapolitan dapat berlangsung dengan baik.

Pengembangan SDM di wilayah minapolitan utamanya dilakukan secara berkelompok. Pada tiap kecamatan terdapat kelembagaan baik dalam 
bentuk kelompok perikanan atau koperasi. Namun begitu, aktivitas kelembagaan ini masih belum optimal karena ada beberapa kelompok yang jarang bertemu. Selain itu, beberapa kelompok juga aktivitasnya masih terbatas pada aspek budi daya padahal masalah utama pelaku usaha perikanan pada aspek pemasaran. Apabila dilihat dari sisi aset dan peralatan, maka tiap kelompok telah memiliki sarana prasarana yang memadai.

Masalah utama dalam pengembangan SDM adalah regenerasi pelaku usaha perikanan. Hampir sebagian besar kelompok belum melakukan regenerasi. Hal ini yang di masa depan akan mengganggu aktivitas usaha perikanan karena semakin bertambah usia maka produktivitasnya semakin turun termasuk adopsi teknologi modern juga semakin melambat.

Nelayan memperoleh modal dari berbagai pihak. Modal terbesar diperoleh dari modal mandiri atau pedagang ikan. Nelayan akan memperoleh pinjaman modal pada awal budi daya atau sebelum memulai aktivitas melaut. Pinjaman modal tersebut akan dikembalikan pada saat panen atau setelah pulang dari aktivitas melaut. Sistem ini sudah umum terjadi pada perikanan di kawasan strategis minapolitan Kabupaten Cilacap.

Permasalahan yang umum terjadi pada aspek permodalan adalah kesulitan nelayan untuk mengakses kredit dari bank. Nelayan menghadapi hambatan berupa kesulitan mengikuti prosedur yang ada di bank maupun tidak memiliki agunan. Keadaan tersebut menunjukkan bahwa akses permodalan nelayan di wilayah strategis minapolitan masih perlu dibenahi utamanya dalam hal perbankan. Selain itu, belum ada pelaku usaha perikanan yang menjalin kemitraan dengan perusahaan sehingga tidak ada modal pinjaman dari lembaga formal.

Aspek pemasaran di kawasan strategis minapolitan telah berlangsung dengan baik dimana nelayan akan menjual produknya ke para pedagang atau ke Tempat Pelelangan Ikan (TPI). Para pedagang tersebut akan mendatangi pembudi daya ikan pada saat masa panen. Sedangkan nelayan perikanan tangkap akan langsung menjual hasil melautnya ke TPI pada saat sampai di daratan. Bahkan, ada pembudi daya udang vaname yang bermitra dengan sebuah perusahaan sehingga mampu mengekspor produknya.

Masalah utama yang dihadapi dalam pemasaran adalah fluktuasi harga. Sebagian besar para nelayan memperoleh harga yang tidak sesuai. Namun prinsip para nelayan adalah produk yang dipasarkan tetap laku terjual dan menghindari terjadinya pembusukan. Hal ini biasa terjadi di berbagai kawasan minapolitan, seperti di Kabupaten Gowa dimana pembudi daya ikan menjual ke pedagang pengepul (Apriliani, Kurniawan \& Hikmah, 2011). Kondisi pemasaran di kawasan minapolitan masih perlu diintervensi untuk meningkatkan kesejahteraan nelayan.

Kecamatan di sekitar wilayah minapolitan memiliki UMKM pengolahan komoditas perikanan. Aktivitas pengolahan menjadi penting dalam peningkatan nilaitambah produksertakesejahteraan pelaku usaha perikanan. Integrasi ini perlu terus ditingkatkan dengan dukungan dari pemerintah daerah melalui mekanisme inisiasi pembentukan kelompok olahan hasil, bantuan peralatan dan kredit serta kegiatan pelatihan dan pendampingan.

\section{Analisis SWOT Kawasan Minapolitan}

Setelah melihat kondisi eksisting kawasan minapolitan, maka selanjutnya perlu dilakukan analisis SWOT untuk menyusun strategi pengembangan. Langkah pertama adalah dengan melihat kondisi internal kawasan minapolitan.

Berdasarkan hasil analisis faktor internal diketahui kekuatan kawasan minapolitan lebih besar daripada kelemahan. Kekuatan terbesar kawasan minapolitan adalah keterampilan nelayan dalam membudi daya kan ikan. Nelayan memperoleh kegiatan penyuluhan dan pelatihan baik dari pemerintah maupun pihak lain. Alasan lain karena pembudi daya ikan dan nelayan telah melaksanakan bisnis tersebut sejak lama sehingga keterampilan dan pengalamannya diperlukan. Kekuatan paling kecil yang dihadapi pelaku usaha perikanaan di minapolitan adalah tingginya serangan organisme pengganggu, terutama budi daya ikan air tawar. Banyak sekali serangan jamur yang menyerang ikan budi daya dan sampai saat ini pembudi daya ikan masih belum mampu mengatasinya.

Kelemahan terbesar di kawasan minapolitan adalah nelayan belum mampu menyimpan produk. Nelayan belum memiliki pengetahuan untuk melakukan penyimpanan serta nelayan lebih senang untuk langsung menjual produknya agar langsung memperoleh uang. Nelayan juga tidak memiliki sarana penyimpanan sehingga akan langsung menjual produk agar produk tidak busuk. Untuk kelemahan terendah yang dihadapi nelayan adalah produksi yang rendah. Sebagian 
Tabel 2. Matriks Faktor Strategi Internal Kawasan Minapolitan di Kabupaten Cilacap. Table 2. Matrix of the Internal Strategy of the Minapolitan Area in the Cilacap Regency.

\begin{tabular}{|c|c|c|c|}
\hline Faktor Strategi Internal / Internal Factor Strategy & $\begin{array}{l}\text { Bobot/ } \\
\text { Weight }\end{array}$ & $\begin{array}{l}\text { Rating/ } \\
\text { Rating }\end{array}$ & $\begin{array}{l}\text { Bobot } \times \text { Rating/ } \\
\text { Weight } \times \text { Rating }\end{array}$ \\
\hline \multicolumn{4}{|l|}{ Kekuatan / Strengths } \\
\hline $\begin{array}{l}\text { Pelaku usaha perikanan berusia produktif / } \\
\text { Fisheries business actors in productive age }\end{array}$ & 17.24 & 2.86 & 49.26 \\
\hline $\begin{array}{l}\text { Pelaku usaha perikanan memiliki keterampilan budi daya/ } \\
\text { Fisheries business actors have good cultivation skill }\end{array}$ & 17.24 & 3.29 & 56.65 \\
\hline $\begin{array}{l}\text { Kemudahan akses memperoleh input perikanan / } \\
\text { Easy access to gets fishery input }\end{array}$ & 13.79 & 3.00 & 41.38 \\
\hline $\begin{array}{l}\text { Peralatan budi daya lengkap / } \\
\text { The cultivation equipment has been completed }\end{array}$ & 13.79 & 3.14 & 43.35 \\
\hline $\begin{array}{l}\text { Organisme pengganggu sedikit / } \\
\text { Few confounding organisms }\end{array}$ & 10.34 & 3.00 & 31.03 \\
\hline $\begin{array}{l}\text { Kemudahan akses permodalan dengan bunga lunak / } \\
\text { Easy access to gets capital with soft interest }\end{array}$ & 13.79 & 2.86 & 39.41 \\
\hline Kemudahan menjual produk/ Easy access to selling products & 13.79 & 3.00 & 41.38 \\
\hline Jumlah Skor Kekuatan / Total Score of Strengths & & & 302.46 \\
\hline \multicolumn{4}{|l|}{ Kelemahan / Weakness } \\
\hline Produksi relatif rendah /Relatively low production & 10.00 & 1.86 & 18.57 \\
\hline $\begin{array}{l}\text { Penerapan GAP dan SOP belum berjalan dengan baik / } \\
\text { The implementation of GAP and SOP is not going well }\end{array}$ & 20.00 & 2.29 & 45.71 \\
\hline $\begin{array}{l}\text { Kemampuan pelaku usaha perikanan dalam penyimpanan produk } \\
\text { masih terbatas / } \\
\text { The limited ability of fisheries business actors in storing products }\end{array}$ & 30.00 & 2.14 & 64.29 \\
\hline $\begin{array}{l}\text { Kelembagaan pengolah hasil belum berkembang / } \\
\text { Production processing institutions have not yet developed }\end{array}$ & 20.00 & 3.14 & 62.86 \\
\hline $\begin{array}{l}\text { Pelaku usaha perikanan kurang mengenal informasi pasar / } \\
\text { Fisheries business actors are not familiar with market information }\end{array}$ & 20.00 & 2.14 & 42.86 \\
\hline Jumlah Skor Kelemahan/Total Score of Weakness & & & 234.29 \\
\hline $\begin{array}{l}\text { Selisih Kekuatan-Kelemahan/Difference of Strenghts - } \\
\text { Weakness }\end{array}$ & & & 68.18 \\
\hline
\end{tabular}

besar wilayah minapolitan memiliki potensi alam yang sangat baik sehingga produksi nelayan dapat optimal.

Selanjutnya analisis SWOT akan melihat kondisi eksternal kawasan minapolitan. Hasil dari analisis ini adalah gambaran mengenai peluang dan ancaman bagi kawasan minapolitan (Tabel 3).

Pada aspek peluang dan ancaman, wilayah minapolitan memiliki skor peluang yang lebih besar. Apabila dilihat secara mendetail, nilai peluang terbesar adalah peningkatan permintaan karena adanya penambahan jumlah penduduk. Secara teoritis, penambahan jumlah penduduk akan meningkatkan konsumsi pangan masyarakat, termasuk nantinya konsumsi produk perikanan. Apalagi dengan semakin meningkatnya kesadaran masyarakat tentang konsumsi protein sehingga membuat konsumsi ikan meningkat pula. Peluang terendah pada kawasan minapolitan adalah kebijakan harga yang ditetapkan pemerintah. Selama ini, kebijakan harga yang diatur pemerintah hanya beras sedangkan untuk produk perikanan belum ada pengaturan dan sangat tergantung pada kondisi pasar.

Ancaman terbesar yang dihadapi nelayan adalah faktor cuaca. Banyak sekali nelayan yang tidak bisa menangkap ikan di laut apabila cuaca dalam kondisi buruk, terutama pada musim penghujan. Begitu pula dengan nelayan pembudi daya ikan dimana apabila cuaca buruk maka akan muncul serangan penyakit pada ikan. Untuk kelemahan terendah yang dihadapi nelayan adalah kebijakan impor. Nelayan di Kabupaten Cilacap tidak merasakan dampak dari kebijakan impor dari beberapa komoditas karena kebutuhan konsumsi ikan di Kabupaten Cilacap selama ini dipenuhi produk lokal bukan dari impor.

\section{Strategi Pengembangan Kawasan}

Sianturi, Masinambow \& Londa (2018) menyatakan perumusan kebijakan perikanan yang tepat sangat penting agar tidak memberikan efek 
Tabel 3. Matriks Faktor Strategi Eksternal Kawasan Minapolitan di Kabupaten Cilacap. Table 3 Matrix of the External Strategy of the Minapolitan Area in the Cilacap Regency.

\begin{tabular}{|c|c|c|c|}
\hline Faktor Strategi Eksternal / External Factor Strategy & $\begin{array}{l}\text { Bobot } l \\
\text { Weight }\end{array}$ & $\begin{array}{c}\text { Rating / } \\
\text { Rating }\end{array}$ & $\begin{array}{l}\text { Bobot } \times \text { Rating/ } \\
\text { Weight } \times \text { Rating }\end{array}$ \\
\hline \multicolumn{4}{|l|}{ Peluang / Opportunities } \\
\hline $\begin{array}{l}\text { Bantuan modal dan peralatan dari pemerintah / Capital and equipment } \\
\text { assistance from the government }\end{array}$ & 30.77 & 2.57 & 79.12 \\
\hline Permintaan produk meningkat / Demand always increases & 30.77 & 2.86 & 87.91 \\
\hline $\begin{array}{l}\text { Himbauan pemerintah mengenai pengaturan budi daya untuk } \\
\text { menstabilkan harga / The government's call for cultivation } \\
\text { arrangements to stabilize prices }\end{array}$ & 23.08 & 2.29 & 52.75 \\
\hline $\begin{array}{l}\text { Kebijakan pemerintah untuk menjaga stabilisasi pasokan dan harga / } \\
\text { Government policies to maintain supply and price stabilization }\end{array}$ & 15.38 & 2.29 & 35.16 \\
\hline \multicolumn{4}{|l|}{ Ancaman / Threats } \\
\hline Cuaca dapat mengganggu produksi / Weather can interfere production & 17.65 & 3.43 & 60.50 \\
\hline Konversi lahan tinggi / High land conversion & 17.65 & 2.14 & 37.82 \\
\hline $\begin{array}{l}\text { Posisi daya tawar pelaku usaha perikanan lemah / The bargaining } \\
\text { position of fishery business actors is weak }\end{array}$ & 17.65 & 2.57 & 45.38 \\
\hline Fluktuasi harga / Price fluctuations & 17.65 & 2.86 & 50.42 \\
\hline Panjangnya rantai pemasaran / The length of the marketing chain & 17.65 & 2.29 & 40.34 \\
\hline Adanya kebijakan impor / There is an import policy & 11.76 & 1.71 & 20.17 \\
\hline Jumlah Skor Ancaman / Total Score of Threats & & & 254.62 \\
\hline Selisih Peluang-Ancaman / Difference of Opportunities - Threats & & & 0.32 \\
\hline
\end{tabular}

negatif bagi nelayan. Dalam rangka pengembangan kawasan minapolitan, Pemerintah Kabupaten Cilacap harus menyusun berbagai strategi. Strategi yang diutamakan adalah S-O atau strategi agresif dengan cara menguatkan pengembangan produk perikanan. Analisis faktor internal menunjukkan kekuatan (strength) yang dimiliki kawasan minapolitan lebih besar daripada kelemahannya karena selisihnya mencapai 68,18 . Hal tersebut menunjukkan kelembagaan SDM dan infrastruktur kawasan minapolitan serta akses sosial ekonomi yang sudah baik, walaupun sebenarnya masih dapat ditingkatkan dengan intervensi kebijakan yang tepat.Sedangkan berdasarkan analisis eksternal, kawasan minapolitan menghadapi peluang lebih besar daripada ancaman. Dari hasil analisis SWOT, tampak bahwa peluang pasar kawasan minapolitan kenyataannya lebih besar daripada ancaman terkait dengan fisik maupun ekonomi yang dihadapi kawasan tersebut dapat dilihat pada Gambar 2.

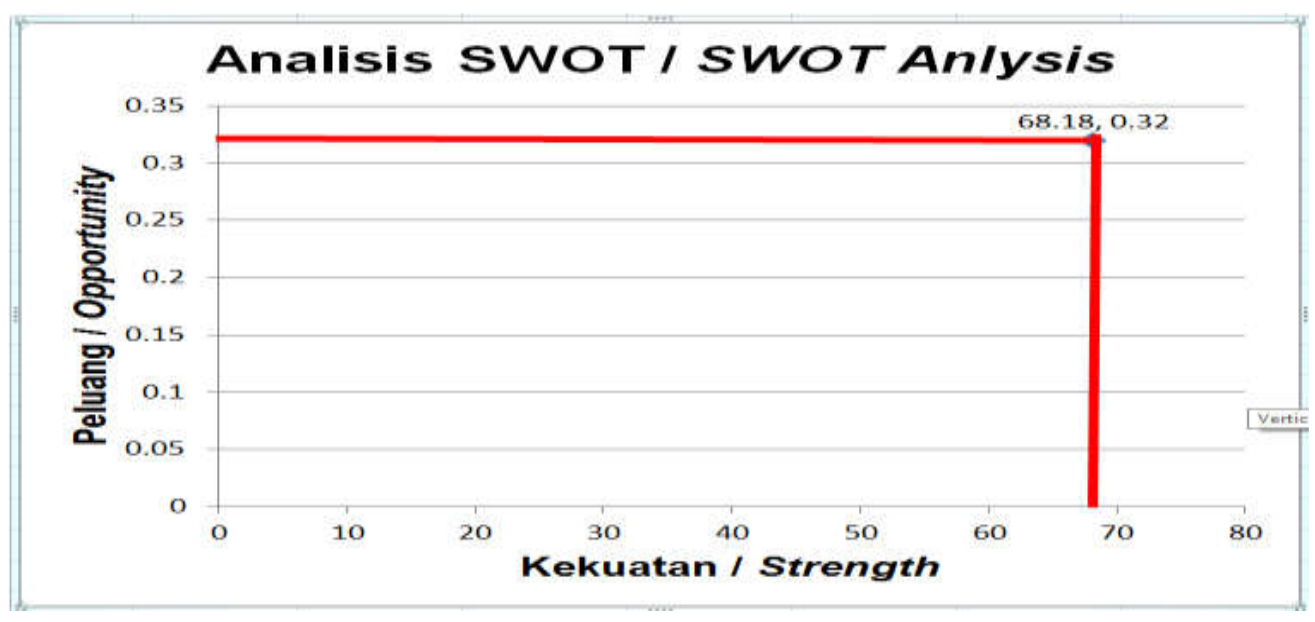

Gambar 2. Matriks Posisi SWOT Kawasan Minapolitan di Kabupaten Cilacap.

Figure 2. Matrix Position of SWOT of Minapolitan Area in the Cilacap Regency.

Sumber: Analisis data primer (2019)/Source: Primary data analysis (2019) 
Tabel 4. Strategi Pengembangan Kawasan Minapolitan di Kabupaten Cilacap. Table 4. Development Strategy of the Minapolitan Area in the Cilacap Regency.

1. Pelaku usaha perikanan berusia produktif/ Fisheries business actors in productive age (S1)

2. Pelaku usaha perikanan memiliki keterampilan budi daya / Fisheries business actors have good cultivation skill (S2)

3. Kemudahan akses memperoleh input perikanan/ Easy access to gets fishery input (S3)

4. Peralatan budi daya lengkap/The cultivation equipment has been completed (S4)

5. Organisme pengganggu sedikit/Few confounding organisms (S5)

6. Kemudahan akses permodalan dengan bunga lunak/ Easy access to gets capital with soft interest (S7)

7. Kemudahan menjual produk / Easy access to selling products (S8)

\section{Peluang (Opportunities)}

1. Bantuan modal dan peralatan dari pemerintah/ Capital and equipment assistance from the government (01)

2. Permintaan produk meningkat / Demand always increases $(\mathrm{O} 2)$

3. Himbauan pemerintah mengenai pengaturan budi daya untuk menstabilkan harga / The government's call for cultivation arrangements to stabilize prices (O3)

4. Kebijakan pemerintah untuk menjaga stabilisasi pasokan dan harga / Government policies to maintain supply and price stabilization (O4)

\section{Strategi S-O (S-O Strategy)}

1. Penguatan kelembagaan perikanan dan regenerasi SDM/ Strengthen the fisheries institutions and regeneration of human resources (S1, S2, O2)

2. Memperluas jaringan kemitraan, baik hulu dan hilir serta sektor lain (pariwisata)/ Expand the partnership network, both upstream to downstream and other sectors (tourism) (S3. S6. S7, O1, O2, O3, O4)

3. Promosi komoditas perikanan/ Promote the fisheries commodities (S4, S5, S7, O2, O4)

4. Pengadaan/pembuatan infrastruktur budi daya dan pemasaran produk/ Procurement / manufacture of cultivation infrastructure and product marketing (S1, S2, S4, S7, O1, O2, O3, O4)

Sumber: Analisis data primer (2019)/Source: Primary data analysis (2019)

Strategi ini diperoleh karena pada analisis SWOT terlihat nilai kekuatan kawasan minapolitan lebih besar dari kelemahannya serta nilai potensi lebih besar dari ancamannya. Namun, perlu juga strategi tersebut diikuti dengan langkah penguatan pada aspek budi daya dan kelembagaan. Strategi tersebut perlu melibatkan pemangku kepentingan sehingga menjadi budaya dan dilaksanakan secara sadar oleh masyarakat (Sugandi, 2011).

Secara detail, strategi yang dapat disusun oleh Pemerintah Kabupaten Cilacap diantaranya:

\section{Penguatan Kelembagaan Perikanan dan Regenerasi SDM}

Strategi ini muncul karena SDM di kawasan minapolitan Kabupaten Cilacap cukup baik dan berpotensi untuk memenuhi permintaan pasar. Namun, kelembagaan perikanan di Kabupaten Cilacap masih perlu terus ditingkatkan karena sebagian besar pelaku usaha perikanan belum menyadari arti pentingnya berkelompok. Padahal, perkembangan kelompok yang baik akan menguatkan daya saing serta kemampuan pelaku usaha perikanan (Haeruddin, 2016). Banyak contoh bagaimana kelompok yang kuat akan meningkatkan kesejahteraan anggotanya, diantaranya petani padi di Jepang mampu berserikat dengan baik membentuk kelompok stani maupun koperasi. Lembaga ini mampu memperkuat posisi tawar pelaku usaha perikanan baik secara ekonomi (pemasaran hasil pertanian) maupun secara politis (usulan kebijakan bagi pemerintah).

Penguatan kelembagaan dapat dilakukan melalui pelatihan manajemen kelompok, pencatatan keuangan dan finansial, dan pemasaran. Pelatihan manajemen berfungsi untuk mengarahkan kelompok membentuk struktur organisasi dan deskripsi tugas secara tepat. Pelatihan pencatatan keuangan dan finansial sangat penting dilakukan karena pelaku usaha perikanan sering melupakan aktivitas ini. Akibatnya banyak pelaku usaha yang 
tidak mengetahui kelayakan usahanya serta kesulitan mengakses modal ke lembaga formal. Pelatihan pemasaran sangat diperlukan kelompok dalam mencari mitra, bernegosiasi serta identifikasi informasi pasar.

Selain penguatan kelembagaan, pelaku usaha perikanan perlu terus diberikan pendidikan dalam rangka pengembangan komoditas perikanan di Kabupaten Cilacap. Pemerintah daerah perlu mendesain pelaku usaha perikanan memiliki usaha yang efektif dan efisien, baik pada subsistem hulu sampai hilir. Berbagai materi mengenai penangkaran benih, teknis budi daya, pengendalian organisme penggangu, pembuatan sarana produksi, pengolahan dan pemasaran perlu secara rutin diberikan kepada pelaku usaha perikanan. Pengusaha perikanan juga perlu diberikan pengetahuan mengenai dampak perubahan iklim yang terlihat pada intensitas serangan organisme pengganggu yang meningkat, banjir, kekeringan dan lainnya. Pemerintah Kabupaten Cilacap harus segera mengadakan mitigasi perubahan iklim dengan melakukan kolaborasi riset untuk dapat memberikan informasi dan strategi mengatasi efek perubahan iklim terhadap perikanan (Listriani \& Roesa, 2015). Bahkan, apabila diperlukan pelaku usaha perikanan perlu diberikan kesempatan studi banding atau magang untuk memperluas wawasannya dalam pengelolaan usaha perikanan.

Pelaku usaha perikanan juga perlu diperkenalkan dengan teknologi modern. Salah satunya adalah penyuluhan online dimana penyuluh dapat membantu mengatasi berbagai permasalahan tanpa harus bertatap muka. Namun begitu, harus dilakukan beberapa langkah persiapan dimana perlu ada pelatihan bagi penyuluh maupun pelaku usaha perikanan agar dapat mengakses teknologi, sarana penunjang sampai dengan jenis aplikasi yang dipakai.

Untuk mendorong regenerasi, Pemerintah Kabupaten Cilacap dapat menyelenggarakan pelatihan agribisnis bagi karang taruna yang bertujuan meningkatkan minat generasi muda bekerja pada sektor perikanan. Langkah lain adalah inisiasi membentuk sekolah atau pendidikan formal untuk sektor perikanan. Jenis pendidikan yang tersedia idealnya dengan konsep Sekolah Menengah Kejuruan atau kerjasama dengan Perguruan Tinggi yang telah ada.

\section{Memperluas Jaringan Kemitraan, Baik Hulu dan Hilir Serta Sektor Lain (Pariwisata).}

Kontribusi sektor pertanian dan perikanan yang begitu besar dalam penyerapan tenaga kerja maupun kontribusi pada PDRB perlu terus dijaga dengan menjalin kemitraan baik dari hulu sampai hilir. Strategi ini muncul karena banyaknya akses penunjang kegiatan minapolitan dalam rangka memanfaatkan peningkatan permintaan konsumen dan dukungan kebijakan pemerintah. Pengembangan kemitraan merupakan salah satu cara yang dapat ditempuh untuk menjamin keberlangsungan usaha dan pekerjaan di sektor perikanan, mendukung peningkatan ekonomi dan sosial penduduk yang lebih luas dan melepas ketergantungan nelayan terhadap lembaga permodalan tradisional, dan sebagai sarana untuk mencapai pembangunan yang lebih adil dan berkelanjutan (Asiati \& Nawawi, 2016).

Pada aspek hulu, Pemerintah Kabupaten Cilacap perlu menjamin tercukupinya kebutuhan sarana produksi yang berkualitas, baik pupuk, pestisida, dan benih/bibit. Kemitraan ini dapat dilakukan baik dengan instansi resmi pemerintah (lembaga penelitian pengembangan) maupun pihak swasta penyedia sarana produksi. Pada subsistem pengolahan, pemerintah daerah perlu menjamin keberlangsungan UMKM serta membuka peluang masuknya industri pengolah hasil perikanan. Hal tersebut karena tingkat keberdayaan ekonomi UMKM pengolah ikan di Kabupaten Cilacap masih rendah (Hendramotko, Istiyanto \& Kusasih, 2015). Pada aspek pemasaran, pemerintah daerah perlu bekerja sama dalam rangka memperluas jangkauan pemasaran produk. Salah satu langkah yang dapat dilakukan adalah dengan kebijakan yang mengikat agar toko waralaba, usaha penginapan dan pariwisata di Kabupaten Cilacap bermitra dengan UMKM yang menghasilkan produk asli Cilacap. Langkah ini mirip dengan yang dilakukan Pemerintah daerah Kulon Progo yang mewajibkan toko waralaba dan penginapan memasarkan produk asli Kulon Progo.

Dukungan terhadap pelaku usaha perikanan juga dapat dilakukan dengan memberikan kemudahan akses kredit. Kredit merupakan insentif yang dapat meningkatkan produksi dan kesejahteraan pelaku usaha perikanan. Dukungan terhadap pelaku usaha perikanan perlu dilakukan dengan memberikan kemudahan akses kredit. 
Banyak langkah dilakukan oleh beberapa negara untuk meningkatkan akses kredit tersebut, diantaranya membentuk bank pertanian/perikanan, kemudahan prosedur ataupun bunga kredit rendah. Langkah ini dapat diadopsi oleh Pemerintah Kabupaten Cilacap, terutama memberikan kredit bunga rendah kepada pelaku usaha perikanan. Pemerintah daerah dapat memanfaatkan bank daerah untuk menjalankan program ini.

Akses kredit juga dapat ditingkatkan dengan Pemerintah Kabupaten Cilacap mengakselerasi pembentukan BUMDES. Dana desa yang besar dapat dimanfaatkan melalui penumbuhan usaha produktif di pedesaan, terutama sektor perikanan. BUMDES ini nantinya diharapkan dapat memberikan pinjaman lunak kepada pelaku usaha perikanan. Fungsi BUMDES juga dapat menjadi penyedia sarana produksi, asuransi maupun saluran pemasaran produk di tiap desa. BUMDES juga dapat bekerja sama dengan lembaga lokal, baik kelompok nelayan ataupun koperasi untuk memberikan bantuan modal. Kelembagaan tersebut nantinya akan mampu meingkatkan efisiensi usaha perikanan (Patria et al., 2014). Dengan begitu, BUMDES akan menjadi salah satu solusi bagi masalah perikanan yang ada saat ini.

Pemerintah Kabupaten Cilacap juga dapat membuka peluang investasi sebesar-besarnya kepada swasta pada sektor perikanan. Dengan begitu, maka sektor perikanan akan dapat berkembang secara intensif dan modern. Namun, harus diingat bahwa langkah ini harus pula diikuti dengan pola kemitraan antara pihak swasta dengan nelayan. Hal ini untuk menjamin bahwa nelayan akan memperoleh manfaat ekonomi dari masuknya investasi ke Kabupaten Cilacap.

Selain pengembangan internal sektor perikanan, maka pemerintah daerah dapat mendesain agar kawasan dapat terintegrasi dengan sektor pariwisata. Hal ini sangat diperlukan dalam pengembangan minapolitan karena program ini merupakan program lintas kementerian yang difokuskan pada pembangunan wilayah perdesaan (Suryawati \& Purnomo, 2011). Beberapa desa wisata dan desa inovasi yang telah dibentuk Pemerintah Daerah Cilacap perlu diarahkan mampu mendukung pengembangan kawasan ini. Kabupaten Cilacap memiliki Desa Wisata dan Desa Inovasi menurut Surat Keputusan Bupati Kabupaten Cilacap Nomor No.071/545/27/2014 dan No.556/213/2012 berjumlah total 16 desa. Desa-desa tersebut seharusnya mampu mendukung untuk memenuhi kebutuhan wisatawan. Kebutuhan tersebut terkait dengan 3 hal yaitu estetika, produk yang dihasilkan, dan aktivitas yang dapat dilakukan di wilayah tersebut. Berdasarkan hasil pengamatan yang dilakukan pada beberapa desa bahwa pengembangan menuju desa inovasi dan wisata belum optimal, terutama untuk mendukung kawasan minapolitan, sehingga desa - desa tersebut membutuhkan pembenahan lebih lanjut. (Purwanto \& Wahyuningsih, 2017). Langkah tersebut dapat dilakukan semisal membuat desa wisata perikanan maupun menciptakan inovasi yang bertujuan mengembangkan produksi, pengolahan ataupun pemasaran produk perikanan.

\section{Promosi komoditas perikanan}

Strategi ini muncul karena kondisi lingkungan yang mendukung untuk memenuhi kebutuhan konsumen. Promosi komoditas perikanan kabupaten sangat diharapkan mampu memperluas wilayah pemasaran hasil. Ekspansi ini perlu dilakukan dalam rangka menjalanakan strategi agresif untuk pengembangan komoditas unggulan. Selain itu, dengan adanya promosi tersebut maka akan membuka peluang masuknya investasi yang besar bagi industri terkait usaha perikanan. Salah satu kegiatan promosi yang dapat dilakukan adalah menyediakan showroom atau ruang pameran berbagai komoditas di Cilacap. Showroom tersebut harus berada di lokasi strategis dekat dengan lokasi pariwisata maupun jalan utama serta dekat dengan kawasan minapolitan. Lokasi ini dapat menjadi tempat transaksi bisnis antara produsen dengan konsumen atau lembaga perantara bisnis. Selain itu, Pemerintah Daerah Kabupaten Cilacap juga perlu mengoptimalkan pemasaran online untuk memasarkan produk perikanan. Program lain adalah sertifikasi dan branding komoditas Kabupaten Cilacap. Langkah ini dalam rangka meningkatkan nilai jual komoditas perikanan Kabupaten Cilacap serta menjadi penciri komoditas. Banyak sekali daerah lain yang telah mengembangkan langkah ini dan berhasil mengembangkan komoditas perikanan.

Pemerintah Kabupaten Cilacap juga perlu secara rutin menyelenggarakan temu usaha. Aktivitas ini dalam rangka mempertemukan pelaku usaha perikanan dengan mitra, terutama eksportir. Komoditas perikanan seperti udang vaname memiliki potensi besar untuk diekspor secara rutin ke negara Asia Timur. 


\section{Pengadaan/Pembuatan Infrastruktur Budi Daya Dan Pemasaran Produk.}

Salah satu kelemahan pengembangan komoditas perikanan di Kabupaten Cilacap saat ini adalah masih rendahnya ketersediaan infrastruktur penunjang baik budi daya maupun pemasaran hasil. Banyak sekali irigasi yang rusak sehingga mengganggu proses produksi perikanan budi daya. Begitu uga dengan sarana jalan yang masih perlu ditingkatkan sehingga memperlambat proses penyampaian input maupun hasil perikanan. Selain mengakibatkan penurunan kualitas hasil perikanan, kerusakan jalan juga berdampak pada peningkatan biaya distribusi. Padahal SDM kawasan minapolitan sangat potensial untuk memanfaatkan seluruh peluan yang ada. Dengan begitu, Pemerintah Kabupaten Cilacap perlu segera mendeteksi berbagai infrastruktur yang dibutuhkan kawasan minapolitan.

Pada subsistem panen, pelaku usaha perikanan membutuhkan bantuan alat mesin yang akan mempercepat waktu panen dan menghemat biaya tenaga kerja. Pada subsistem pemasaran, pemerintah daerah perlu menyediakan infrastruktur yang memungkinkan nelayan dapat langsung berinteraksi dengan konsumen serta adanya jaminan kepastian harga jual produk. Kebutuhan infrastruktur tersebut antara lain Tempat Pelelangan Ikan, pasar hasil, pasar lelang maupun infrastruktur yang lain. Infrastruktur tersebut nantinya dapat meningkatkan kinerja perikanan (Alfons, Tupamahu \& Abrahamsz, 2018). Selain itu, infrastruktur tersebut akan berdampak bagi pertumbuhan sektor ekonomi dan kesejahteraan masyarakat (Suherman \& Dault, 2009).

\section{KESIMPULAN DAN REKOMENDASI KEBIJAKAN}

\section{Kesimpulan}

Kawasan minapolitan di Kabupaten Cilacap telah berkembang dengan baik. Kekuatan utama pengembangan kawasan minapolitan ini adalah kondisi alam yang bagus serta didukung sumber daya manusia yang cukup baik sehingga mampu menghasilkan produk perikanan dalam jumlah yang banyak. Namun begitu, masaih ada peluang untuk meningkatkan performaminapolitan Kabupaten Cilacap karena kawasan ini sebenarnya masih menghadapi masalah infrastruktur yang rusak serta akses permodalan, pemasaran, dan pengolahan hasil yang belum sepenuhnya mendukung pengembangan minapolitan.

\section{Rekomendasi Kebijakan}

Untuk meningkatkan kinerja kawasan minapolitan, Kabupaten Cilacap perlu melakukan strategi S-O melalui penguatan kelembagaan perikanan dan regenerasi SDM melalui penyuluhan, pelatihan, dan magang; memperluas jaringan kemitraan, baik hulu dan hilir serta sektor lain (pariwisata); melalui kerja sama dengan lembaga perbankan dan pemasaran serta promosi komoditas perikanan (event promosi dan media online); dan pengadaan/pembuatan infrastruktur budi daya dan pemasaran produk.

\section{UCAPAN TERIMA KASIH}

Penulis mengucapkan terima kasih kepada Badan Perencanaan dan Penelitian Pembangunan Daerah (Bappelitbangda) Kabupaten Cilacap yang telah mendanai pelaksanaan penelitian ini.

\section{PERNYATAAN KONTRIBUSI PENULIS}

Dengan ini kami menyatakan bahwa kontribusi masing-masing penulis terhadap pembuatan karya tulis adalah: Agus Dwi Nugroho sebagai kontributor utama, Andi Rifani, Winaryo, Edy Masduqi, Dyah Wahyuning Tyas, Rochma Widayanti, Reni Aqwil Masithah, Ridwan Dicky Romadon, Teguh Sulissetiyo, Reiningsih, Alwi Handono Topo sebagai kontributor anggota. Penulis menyatakan bahwa telah melampirkan surat pernyataan kontribusi penulis.

\section{DAFTAR PUSTAKA}

Alfons, J. M., Tupamahu, A., \& Abrahamsz, J. (2018). Evaluasi peran dan strategi pengelolaan pangkalan pendaratan ikan erie di Kota Ambon. Jurnal Manajemen Sumberdaya Perairan, 14(2), 66-75. Retrieved from : https://ojs3.unpatti.ac.id/ index.php/triton/article/view/802.

Apriliani, T., Kurniawan, T., \& Hikmah. (2011). Identifikasi permasalahan dan peluang perbaikan pengembangan kawasan minapolitan Kabupaten Gowa. Jurnal Sosial Ekonomi Kelautan dan Perikanan, 6(2), 116-130. doi: 10.15578/jsekp. v6i2.5768.

Asiati, D., \& Nawawi. (2016). Kemitraan di sektor perikanan tangkap : strategi untuk kelangsungan usaha dan pekerjaan. Jurnal Kependudukan Indonesia, 11(2), 103-118. doi: 10.14203/jki. v11i2.204.

Febriyanti, R. E. (2013). Kontribusi pengembangan kawasan minapolitan kampung lele terhadap pendapatan petani lele di Desa Tegalrejo Sawit 
Boyolali. Economics Development Analysis Journal, 2(4), 396-408. doi: 10.15294/edaj. v2i4.3208,

Gurel, E., \& Tat, M. (2017). Swot analysis: a theoretical review. The Journal of International Social Research, 10(51), 994-1006. doi: 10.17719/ jisr.2017.1832.

Haeruddin. (2016). Kajian kelembagaan lokal dalam pemanfataan sumberdaya perikanan tangkap di Kabupaten Maros (studi kasus Desa Pajjukukang Kecamatan Bontoa). Agrovital, 1(1), 12-20. doi: 10.35329/agrovital.v1i1.79

Hendramotko, C., Istiyanto, B., \& Kusasih, I. A. K. R. (2015). Pengembangan model pemberdayaan bagi pengolah ikan guna meningkatkan pendapatan (studi kasus pada pengolah ikan di Kabupaten Cilacap). Jurnal Paradigma, 12(2), 158-178. Retrieved from: https://journal.uniba. ac.id/index.php/PRM/issue/view/7

Kementerian Kelautan dan Perikanan. (2013). Pengembangan Kawasan Minapolitan. Jakarta: Sekretariat Jenderal Kementerian Kelautan dan Perikanan.

Kurniawan, H. D. P. (2018). Evaluasi dampak program pengembangan kawasan minapolitan berbasis perikanan budi daya bagi masyarakat Desa Gondosuli Kecamatan Gondang Kabupaten Tulungagung. Kebijakan dan Manajemen Publik, 6(2), 1-14. Retrieved from http:// journal.unair.ac.id/download-fullpapers-kmpd65ec19130full.pdf.

Listriani, S., \& Roesa, N. (2015). Kebijakan pemerintah daerah dalam menghadapi perubahan iklim terhadap sektor perikanan di Aceh. Kanun $J$ urnal IImu Hukum, 17(3), 433-455. Retrieved from http://jurnal.unsyiah.ac.id/kanun/article/ view/6079.

Nuryanto, A., Bhagawati, D., Abulias, M . N., \& Indarmawan, (2015). Fauna ikan di Sungai Cikawung Kabupaten Cilacap Jawa Tengah. Jurnal Iktiologi Indonesia, 15(1), 25-37. doi. org/10.32491/jii.v15i1.73.

Pancawati, Y. D. (2015). Pengembangan kawasan minapolitan (studi kasus : pelabuhan perikanan Samudera Cilacap). Jurnal Pembangunan Wilayah dan Kota, 11(3), 364-375. doi: 10.14710/ pwk.v11i3.17597.

Pangesti, T. P., Wiyono, E. S., Baskoro, M. S., Nurani, T. W., \& Wiryawan, B. (2015). Status bio-ekonomi sumberdaya udang di Kabupaten Cilacap. Jurnal Sosial Ekonomi Kelautan dan Perikanan, 10(2), 149-157. doi: 10.15578/jsekp.v10i2.1256.

Patria, A. D., Adrianto, L., Kusumastanto, T., Kamal, M. M., \& Dahuri, R. (2014). Biaya transaksi usaha perikanan skala kecil di Kabupaten Cilacap. Jurnal Sosial Ekonomi Kelautan dan Perikanan, 9(2), 247-254. doi: 10.15578/jsekp.v9i2.1225.
Purwanto, R., \& Wahyuningsih, C. D. (2017). Inovasi daerah dalam pembangunan desa berbasis potensi desa. Mimbar Admnistrasi, 1(1), 35-45. Retrieved from http://jurnal.untagsmg.ac.id/index. $\mathrm{php} / \mathrm{mia} /$ article/view/570.

Ramadhan, A., \& Hafsaridewi, R. (2012). Dampak perubahan lingkungan terhadap perkembangan aktivitas ekonomi dan kesejahteraan masyarakat pesisir di kawasan Segara Anakan. Jurnal Sosial Ekonomi Kelautan dan Perikanan, 7(1), 33-53. doi: org/10.15578/jsekp.v7i1.5734.

Satria, A. I. W \& Kurnia, R. (2017). Struktur populasi ikan cakalang (Katsuwonus pelamis, Linnaeus 1758) : famili Scombridae : perairan pesisir selatan Laut Jawa. Jurnal Pengelolaan Perikanan Tropis, 1(1), 1-7. doi: 10.29244/jppt, 1,01,1-9.

Sianturi, S., Masinambow, V. A. J., \& Londa A. T. (2018). Dampak regulasi sektor perikanan tangkap ikan terhadap pertumbuhan pdrb di Kota Bitung. Jurnal Berkala Ilmiah, Vol, 18(1), 103-113. Retrieved from https://ejournal.unsrat.ac.id/index.php/jbie/ article/view/19848.

Sugandi. (2011). Pengelolaan sumberdaya pantai. Geo, 11(1), 50-58. doi: 10.17509/gea.v11i1.1647.

Suherman, A., \& Dault, A. (2009). Analisis dampak sosial ekonomi keberadaan Pelabuhan Perikanan Nusantara Brondong Lamongan Jawa Timur. Jurnal Saintek Pertanian, 5(1), 25-30.

Suryawati, S. H \&. Purnomo, A. H. (2011). Analisis ex-ante keberlanjutan program minapolitan. Jurnal Sosial Ekonomi Kelautan dan Perikanan, 6(1), 61-81. doi: 10.15578/jsekp.v6i1.5756. Retrieved from https://core.ac.uk/download/pdf/11716713.pdf.

Triyanti, R., Wijaya, R. A., Koeshendrajana, S., \& Priyatna, F. N. (2010). Karakteristik dan nilai manfaat langsung sumber daya pesisir (studi kasus di Perairan Segara Anakan Kabupaten Cilacap). Jurnal Kebijakan Sosial Ekonomi Kelautan dan Perikanan, 5(1), 31-46. doi: 10.15578/jsekp. v5i1.5790.

Widyaningrum, T. (2016). Faktor-faktor pengembangan kawasan minapolitan di Kecamatan Ngemplak Kabupaten Sleman. Jurnal Bumi Indonesia, 5(3), 1-10. Retrieved from http://lib.geo.ugm.ac.id/ojs/ index.php/jbi/article/view/530.

Wiratama, A. (2016). Dampak implementasi program minapolitan terhadap kesejahteraan masyarakat di Kecamatan Muncar Kabupaten Banyuwangi. Kebijakan dan Manajemen Publik, 4(3), 14-26. Retrieved from http://journal.unair.ac.id/ download-fullpapers-kmp17c1301972full.pdf. 